\title{
Cbln1 Regulates Rapid Formation and Maintenance of Excitatory Synapses in Mature Cerebellar Purkinje Cells In Vitro and In Vivo
}

\author{
Aya Ito-Ishida, ${ }^{1}$ Eriko Miura, ${ }^{2}$ Kyoichi Emi, ${ }^{1}$ Keiko Matsuda, ${ }^{1}$ Takatoshi Iijima, ${ }^{1}$ Tetsuro Kondo, ${ }^{1,3}$ Kazuhisa Kohda, ${ }^{1}$ \\ Masahiko Watanabe, ${ }^{2}$ and Michisuke Yuzaki ${ }^{1}$ \\ ${ }^{1}$ Department of Physiology, School of Medicine, Keio University, Tokyo 160-8582, Japan, ${ }^{2}$ Department of Anatomy, School of Medicine, Hokkaido \\ University, Sapporo 060-8638, Japan, and ${ }^{3}$ Molecular Neurophysiology, National Institute of Advanced Industrial Science and Technology, Tsukuba 305- \\ 8566, Japan
}

\begin{abstract}
Although many synapse-organizing molecules have been identified in vitro, their functions in mature neurons in vivo have been mostly unexplored. Cbln1, which belongs to the $\mathrm{C} 1 \mathrm{q}$ /tumor necrosis factor superfamily, is the most recently identified protein involved in synapse formation in the mammalian CNS. In the cerebellum, Cbln1 is predominantly produced and secreted from granule cells; $c b l n 1$ null mice show ataxia and a severe reduction in the number of synapses between Purkinje cells and parallel fibers (PFs), the axon bundle of granule cells. Here, we show that application of recombinant Cbln1 specifically and reversibly induced PF synapse formation in dissociated $c b \ln 1$-null Purkinje cells in culture. Cbln1 also rapidly induced electrophysiologically functional and ultrastructurally normal PF synapses in acutely prepared $c b \ln 1$-null cerebellar slices. Furthermore, a single injection of recombinant Cbln1 rescued severe ataxia in adult $c b \ln 1$-null mice in vivo by completely, but transiently, restoring PF synapses. Therefore, Cbln1 is a unique synapse organizer that is required not only for the normal development of PF-Purkinje cell synapses but also for their maintenance in the mature cerebellum both in vitro and in vivo. Furthermore, our results indicate that Cbln 1 can also rapidly organize new synapses in adult cerebellum, implying its therapeutic potential for cerebellar ataxic disorders.
\end{abstract}

Key words: cerebellum; Purkinje cell; synaptogenesis; mouse; cerebellin; C1q; parallel fiber

\section{Introduction}

The proper formation of synapses is essential to establish precise neuronal circuits in the mammalian CNS. During development, after growing axons find the correct paths to their target regions, presynaptic and postsynaptic specializations are assembled subsequently and aligned precisely. The analysis of synapse formation in vitro has recently identified various "synapse organizers" involved in these processes (Fox and Umemori, 2006). Several cell adhesion molecules, such as SynCAM (Biederer et al., 2002), neurexin/neuroligin (Chih et al., 2005), and EphB/ephrinB (Kayser et al., 2006; Aoto et al., 2007), and secreted molecules, such as Wnt-7a (Hall et al., 2000), FGF22 (Umemori et al., 2004), and Narp/NP-1/NPR (O’Brien et al., 1999; Xu et al., 2003), have been shown to induce the differentiation and maturation of presynaptic or postsynaptic structures in CNS neurons in vitro. Neverthe-

Received March 8, 2008; revised April 15, 2008; accepted April 26, 2008.

This work was supported by a grant-in-aid from the Ministry of Education, Culture, Sports, Science, and Technology, the Sankyo Foundation of Life Science (M.Y.), a Research Fellowship for Young Scientists, the Japan Society for the Promotion of Science (A.I.-I.), and the Naito Memorial Foundation (K.M.). We thank Dr.J.I. Morgan for cbln1-null mice and J. Motohashi, K. Yoshikawa, and S. Narumi for their technical support.

Correspondence should be addressed to Michisuke Yuzaki, Department of Physiology, Keio University School of Medicine, 35 Shinanomachi, Shinjuku-ku, Tokyo 160-8582, Japan. E-mail: myuzaki@a5.keio.jp.

DOI:10.1523/JNEUROSCI.1030-08.2008

Copyright $\odot 2008$ Society for Neuroscience $\quad$ 0270-6474/08/285920-11\$15.00/0 less, their requirement for the maintenance of synapses or for new synapse formation in the adult CNS in vivo remains primarily unknown.

Cbln 1 is the most recently identified protein involved in synapse formation in the CNS (Hirai et al., 2005). Cbln1 belongs to a Cbln subfamily (consisting of Cbln1-Cbln4) of the C1q/tumor necrosis factor (TNF) superfamily. Members of this superfamily, including C1q, ACRP30/adiponectin/adipoQ, and TNF $\alpha$, serve diverse roles in intercellular communication (Kishore et al., 2004; Yuzaki, 2008). In the cerebellum, Cbln 1 is predominantly secreted from granule cells and plays essential roles in cerebellar functions (Hirai et al., 2005; Miura et al., 2006). Mice lacking a gene encoding $c b \ln 1$ ( $c b \ln 1$-null) displayed severe ataxia and profound abnormality at the excitatory synapses formed between parallel fibers (PFs) (axons of granule cells) and Purkinje cells. Although the number of dendritic spines was normal, $80 \%$ did not form synapses with PFs and remained as "free spines" in cbln1-null Purkinje cells. Furthermore, $>60 \%$ of the remaining synapses were morphologically abnormal, because the postsynaptic densities (PSDs) were longer than the presynaptic active zones (Hirai et al., 2005). These findings indicate that Cbln 1 is indispensable for synapse formation between PFs and Purkinje cells in vivo. However, whether Cbln 1 is necessary for the maintenance of synapses in the adult cerebellum remained unclear. In addition, whether uninnervated spines in mature $c b \ln 1$-null Pur- 
kinje cells could be restored by the application of Cbln 1 remained unknown.

To address these issues, we examined the effects of recombinant Cbln 1 on PF synapses in mature Purkinje cells. We showed that the application of recombinant Cbln1 specifically induced PF synapse formation in dissociated $c b \ln 1$-null Purkinje cells in a reversible manner. Cbln1 also rapidly induced functional PF synapses in cerebellar slices acutely prepared from young $c b \ln 1$-null mice. Furthermore, a single application of recombinant Cbln 1 rescued severe ataxia by rapidly inducing PF synapses in adult $c b \ln 1$-null mice. These findings not only revealed an essential role of Cbln 1 in maintaining synapses but also its potential to induce new synapses in adult cerebellum.

\section{Materials and Methods}

Cell cultures. Primary dissociated cerebellar cultures were prepared from day-of-birth wild-type or $c b \ln 1$-null mice as described previously (Furuya et al., 1998). Cells were suspended in a culture medium containing $10 \%$ fetal calf serum at a density of $3 \times 10^{5}$ cells and plated on plastic coverslips (diameter, $13.5 \mathrm{~mm}$ ). After incubation in $5 \% \mathrm{CO}_{2}$ for $3 \mathrm{~h}$, the cells were washed with $600 \mu \mathrm{l}$ of DMEM/F12 (Invitrogen), and $400 \mu \mathrm{l}$ of serum-free culture medium was added to each well. Half of the culture medium was replaced once a week. All procedures related to the care and treatment of animals were approved by the Keio University School of Medicine Animal Resource Committee.

Human embryonic kidney 293 tSA (HEK293) cells (gift from Dr. R. Horn, Thomas Jefferson University School, Philadelphia, PA) were cultured in DMEM (Invitrogen) supplemented with $10 \%$ fetal calf serum and L-glutamine ( $1 \mathrm{mM}$ ) and grown in $10 \% \mathrm{CO}_{2}$ at $37^{\circ} \mathrm{C}$.

Preparation of recombinant Cbln1. We added cDNA encoding a hemagglutinin (HA) tag to the $5^{\prime}$-end of the wild-type or mutant Cbln1 cDNA (HA-Cbln1); the sequence was then added to the $3^{\prime}$-end of the signal sequence. To confirm the structural specificity of Cbln1, cysteine 34 and cysteine 38 were replaced with serines to generate a mutant Cbln 1 (dS-Cbln1), which cannot form a hexamer (Bao et al., 2005), by a standard PCR-based mutagenesis. For the purification of the recombinant Cbln 1, cDNA that encoded a $6 \mathrm{X}$ His tag was added to the $5^{\prime}$-end of the HA tag (His-HA-Cbln1). The cDNAs were cloned into the pCAGGS expression vector (provided by Dr. J. Miyazaki, Osaka University, Osaka, Japan) and transfected into HEK293 cells using CellPhect (GE Healthcare). After $6 \mathrm{~h}$, the culture medium was replaced with either primary culture medium (Furuya et al., 1998) or chemically defined 293 (CD293) medium (Invitrogen), and the medium was collected $48 \mathrm{~h}$ later. His-HACbln1 was purified using a Talon metal affinity column (BD Biosciences) as described previously (Matsuda et al., 2005). The concentration of recombinant HA-Cbln1 in the medium was quantified using an immunoblot analysis with purified His-HA-Cbln 1 as the standard. To apply the HA-Cbln1 to acute slices, CD293-based medium was dialyzed using artificial CSF (aCSF) (see below for contents) for $2 \mathrm{~d}$ before usage. For the in vivo injection, the CD293-based medium was concentrated using centrifugal filter devices (Centriplus YM-10 and Microcon YM-100; Millipore). After $15 \mathrm{ml}$ of the medium was concentrated to $\sim 50 \mu \mathrm{l}$, the medium was washed twice with $500 \mu \mathrm{l}$ of PBS before recovery from the Microcon YM-100.

Immunohistochemistry. Cultured cerebellar cells at 21-27 d in vitro (DIV) were fixed with PBS containing 4\% paraformaldehyde for $20 \mathrm{~min}$ on ice. The cells were fixed additionally with $100 \%$ methanol at $-20^{\circ} \mathrm{C}$ for $10 \mathrm{~min}$ for synaptophysin immunostaining. After the cells were permeabilized using $0.4 \%$ Triton X-100 in PBS containing 2\% bovine serum albumin and $2 \%$ normal goat serum for $1 \mathrm{~h}$ at room temperature, the cells were treated with a primary antibody against calbindin (1:1000; Millipore), synaptophysin (1:500; mouse; Sigma-Aldrich), vesicular glutamate transporter 1 (VGluT1) (1:500; goat), vesicular GABA transporter (VGAT) (1:1000; guinea pig), or HA (1:1000; mouse; Covance Research Products). The bound antibodies were detected using secondary antibodies that were conjugated with either Alexa 488 or 546 (1:1000; Invitrogen). To immunostain VGluT1, donkey serum was used instead of goat serum.
Images were obtained using a confocal microscope (C1si; Nikon). To quantify the signal intensity of the presynaptic markers that were colocalized on the dendrites of the Purkinje cells, three square images of $30 \times$ $30 \mu \mathrm{m}$ were taken at the most distal region of the dendrites on each cell. All images were taken by gains and exposures at fixed values for each fluorescent channel. The raw images were analyzed using IP-lab software (v. 3.61; Scanalytics). Calbindin-immunopositive regions were selected using macro "auto-segmentation." After subtracting the background level, the average intensity of the presynaptic markers within the segmented area was divided by that of either calbindin or parvalbumin. The values from three regions were averaged to represent the data for each cell. For each analysis, eight different cells per experiment were analyzed, and three independent experiments were performed. The number of neurons was counted as the $n$ for statistical analysis. When wild-type and $c b \ln 1$-null cells were compared, the cells were prepared on the same day or within two consecutive days and were fixed and analyzed on the same day.

Electrophysiology. Sagittal slices (200 $\mu \mathrm{m}$ thick) of cerebellum were prepared, and whole-cell patch-clamp recordings from Purkinje cells were made at room temperature, as described previously (Hirai et al., 2005). The cells were superfused with aCSF containing the following (in mM): $125 \mathrm{NaCl}, 2.5 \mathrm{KCl}, 2 \mathrm{CaCl}_{2}, 1 \mathrm{MgCl}_{2}, 26 \mathrm{NaHCO}_{3}, 1.25 \mathrm{NaH}_{2} \mathrm{PO}_{4}$, 10 glucose, and 0.1 picrotoxin (Sigma-Aldrich). To record miniature EPSCs (mEPSCs), $1 \mu \mathrm{m}$ tetrodotoxin (Wako Pure Chemical Industries) was added to the aCSF. The patch pipettes had a resistance of 2-4 M $\Omega$ when filled with intracellular solution containing $65 \mathrm{~mm}$ potassium gluconate, $65 \mathrm{~mm}$ methane sulfonate, $10 \mathrm{~mm} \mathrm{KCl}, 20 \mathrm{~mm}$ HEPES, $1 \mathrm{~mm}$ $\mathrm{MgCl}_{2}, 4 \mathrm{~mm} \mathrm{Na}_{2} \mathrm{ATP}, 1 \mathrm{~mm} \mathrm{NaGTP}$, and 0.4 mm EGTA. The Purkinje cells were clamped at $-70 \mathrm{mV}$ to record the PF-evoked EPSCs (PFEPSCs) and at $-90 \mathrm{mV}$ for the mEPSCs. An Axopatch 1300B amplifier and Clampex 9.2 software (Molecular Devices) were used for the data recording and analysis. Series resistance and leak currents were monitored continuously, and the recordings were terminated if the parameters changed significantly. Miniature events were counted and analyzed off-line using the Mini Analysis Program (version 6.0.3; Synaptosoft). The threshold for the detection of an event was set at a level five times higher than the root-mean-square of the noise. The averaged frequency and amplitude were obtained from 200 events by continuous recording up to $240 \mathrm{~s}$.

To rapidly examine the effect of Cbln 1 , a higher concentration of HA-Cbln $1(30 \mu \mathrm{g} / \mathrm{ml})$ than that used for the cell cultures was used in the acute slice preparations. With this concentration, significant increases in synaptophysin immunoreactivity were also observed as early as $9 \mathrm{~h}$ in cultured Purkinje cells (supplemental Fig. 1, available at www.jneurosci.org as supplemental material). As a control, we used slices treated with the control medium and prepared from nontransfected HEK293 cells.

In vivo experiment. Adult $c b \ln 1$-null mice (7-8 weeks of age) were anesthetized with the intraperitoneal injection of ketamine $(80 \mathrm{mg} / \mathrm{kg}$ body weight) and xylazine ( $20 \mathrm{mg} / \mathrm{kg}$; Sigma-Aldrich). As described previously (Hirai et al., 2003), a small hole in the occipital bone was made with a dental drill, and the dura matter was ablated. A 33 gauge microsyringe needle was inserted on the surface of the cerebellar vermis, and the solution containing Cbln 1 was injected into the subarachnoidal space at a rate of $40 \mu \mathrm{l} / \mathrm{h}$. For the rotarod test, mice were placed on a $3 \mathrm{~cm}$ (diameter) rod rotating at a constant rate of 10 or $20 \mathrm{rpm}$, four times a day, before and after the injection of the Cbln1-containing medium. Each run was terminated once the mouse had stayed on the rod for $120 \mathrm{~s}$.

Immunoblotting. The whole cerebellums of $c b \ln 1$-null mice were homogenized in $0.32 \mathrm{~m}$ sucrose and $5 \mathrm{~mm}$ HEPES-NaOH, pH 7.4, and centrifuged at $800 \times g$ for $10 \mathrm{~min}$ (Inamura et al., 2006). The supernatant was centrifuged at $12,000 \times g$ for $20 \mathrm{~min}$, and the pellet (P2 fraction) was solubilized in SDS sample buffer. The sample was subjected to SDSPAGE and analyzed using immunoblotting. The injected Cbln 1 within the P2 fraction was detected by antibodies against HA or Cbln1 (1:200; rabbit).

Electron microscopy. For the in vivo HA-Cbln 1 administration experiments, mice under deep pentobarbital anesthesia were perfused transcardially with $2 \%$ paraformaldehyde $/ 2 \%$ glutaraldehyde in $0.1 \mathrm{~m}$ sodium 
phosphate buffer (PB), pH 7.2. Parasagittal microslicer sections of the cerebellum $(300 \mu \mathrm{m})$ were postfixed for $2 \mathrm{~h}$ with $1 \% \mathrm{OsO}_{4}$ in $0.1 \mathrm{M}$ $\mathrm{PB}$. After block staining in $1 \%$ aqueous uranyl acetate solution and dehydration with graded alcohols, the sections were embedded in Epon 812. Ultrathin sections $(70 \mathrm{~nm})$ were made using an ultramicrotome (Leica) and stained with $2 \%$ uranyl acetate for $5 \mathrm{~min}$ and mixed lead solution for $2 \mathrm{~min}$. Electron micrographs were taken of the molecular layer using an H7100 electron microscope (Hitachi) at $4000 \times$ and printed at $16,000 \times$. The numbers of normal and free spines of the Purkinje cells in each condition were counted using 5-10 micrographs that were taken randomly, and the profile density per $100 \mu \mathrm{m}^{2}$ of the counted neuropil area was calculated. To evaluate the reliability of the spine density calculated from single plane sections and to estimate the percentage of mismatched synapses, which had PSDs that were longer than the active zones, serial transverse sections were analyzed $2 \mathrm{~d}$ after the injection of either control or HA-Cbln1 medium, as described previously (Hirai et al., 2005).

For the electron microscopy studies of acute cerebellar slices, $250-\mu \mathrm{m}$-thick slices treated with aCSF containing Cbln 1 for $8 \mathrm{~h}$ were immersed in $2 \%$ paraformaldehyde/ $2 \%$ glutaraldehyde in a microwave for $22 \mathrm{~s}$, causing the temperature of the fixative to be raised from 30 to $40^{\circ} \mathrm{C}$ (Jensen and Harris, 1989). After embedding in Epon 812, ultrathin sections (70 $\mathrm{nm})$ were obtained at a depth of 50-100 $\mu \mathrm{m}$ from the surface. Electron micrographs were taken of the lower half of the molecular layer.

Statistical analysis. Data were analyzed using a Student's $t$ test, unless otherwise stated. Data are expressed as the mean \pm SEM. Statistical significance was assumed when $p<0.05$.

\section{Results}

Exogenous Cbln 1 specifically induces PF synapses in cbln1-null Purkinje cells in vitro

First, we examined whether the application of recombinant Cbln1 could induce synapse formation in cbln1-null Purkinje cells in vitro. The density of the synapses on the dendrites of the Purkinje cells was estimated by immunohistochemical analysis using antibodies against synaptophysin and calbindin, markers for presynaptic terminals and Purkinje cells, respectively, in cultured cerebellar neurons (Fig. 1). As observed in cbln1-null cerebellar slices (Hirai et al., 2005), the average intensity of synaptophysin immunoreactivity along the dendrites of the Purkinje cells (Fig. $1 A$, yellow dots in merged images) was significantly decreased in cerebellar cultures prepared from $c b l n 1$-null mice, compared with those from wild-type mice $(n=$ 24; $p<0.0001$ ) (Fig. $1 A, B$ ). Therefore, in vitro cultures could recapitulate synapse hypoplasia observed in cbln1-null Purkinje cells in vivo (Hirai et al., 2005).

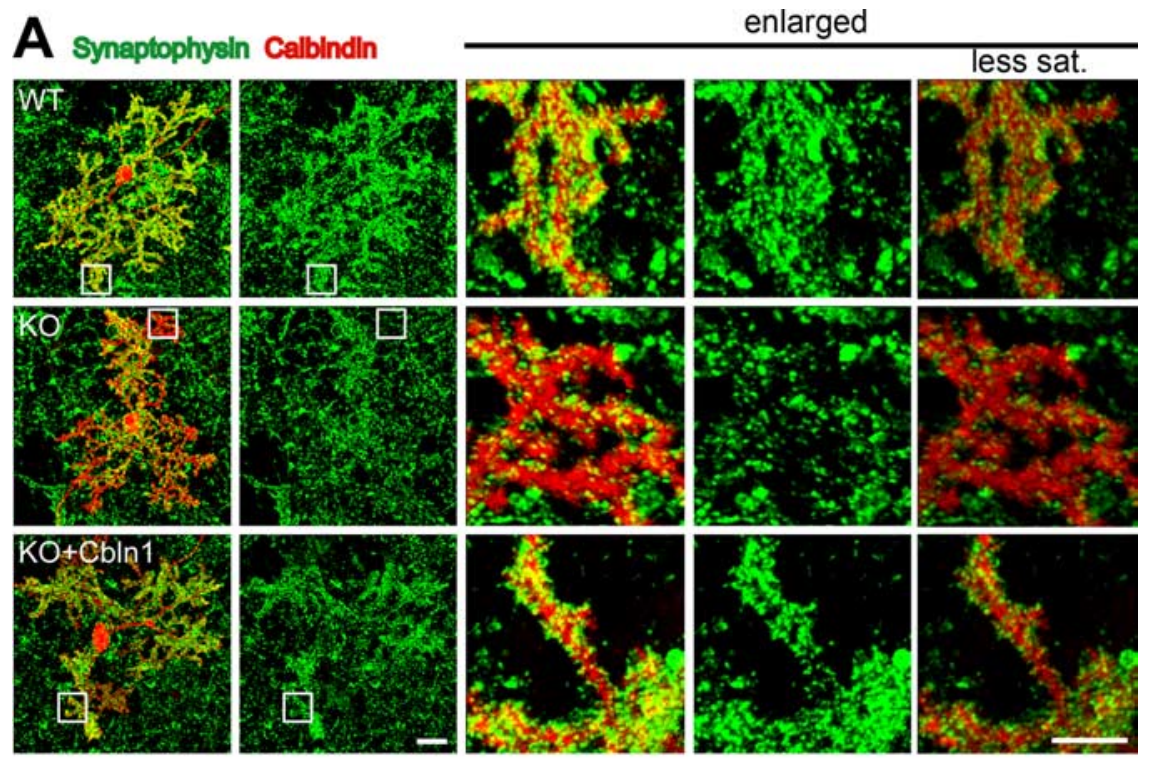

B

\section{Synaptophysin Calbindln}
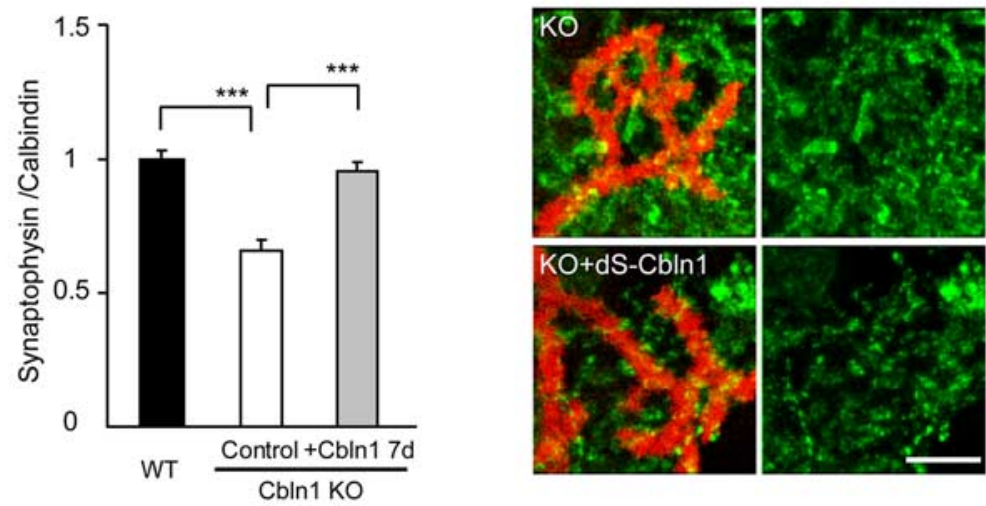

VGLUT1 Calbindln less sat.
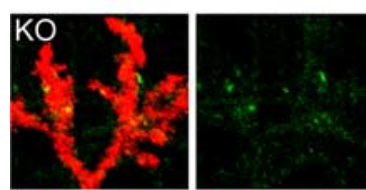

\section{less sat.}
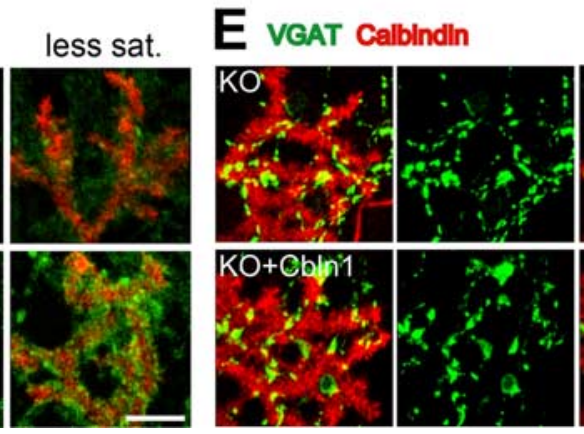

less sat.
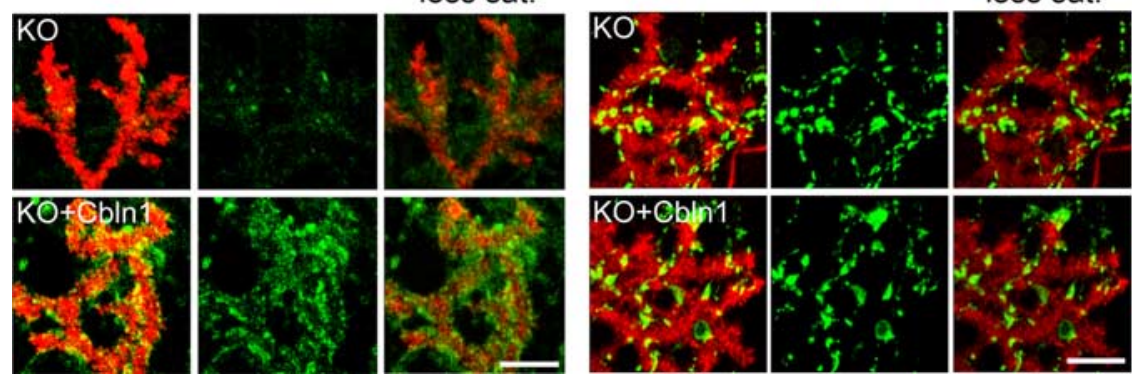

Figure 1. Excitatory synapse formation induced by exogenous Cbln1 in cultured Purkinje cells. $\boldsymbol{A}$, Representative images of cultured Purkinje cells at 21 DIV, prepared from wild-type (WT) and cbln1-null mice [knock-out (KO)] and immunostained against calbindin (red) and synaptophysin (green). The three columns on the right show enlarged views of the boxed regions in the two left columns. The far right column shows the images taken with reduced gain and saturation (less sat.) settings. $\boldsymbol{B}$, The intensity of synaptophysin immunoreactivity is strong at the distal dendrites in WT cells but significantly weaker in cbln1-null cells. Incubation with exogenous $\mathrm{Cbln} 1(3 \mu \mathrm{g} / \mathrm{ml})$ in the medium for $7 \mathrm{~d}$ completely restored the reduction in the synaptophysin signal. The data were normalized to the averages of the wild-type control cells for each experiment $(n=24$ cells; 3 independent experiments; $\left.{ }^{* * *} p<0.0001\right)$. C, Images of distal dendrites of cultured Purkinje cells stained with calbindin (red) and synaptophysin (green). Incubation with a mutant $\mathrm{Cb} \ln 1(\mathrm{dS}-\mathrm{Cb} \ln 1 ; 3 \mu \mathrm{g} / \mathrm{ml})$ did not change synaptophysin signals in cbln1-null Purkinje cells. $\boldsymbol{D}, \boldsymbol{E}$, Images of distal dendrites of cultured Purkinje cells stained with calbindin (red) and either VGluT1 ( $\boldsymbol{D}$, green) or VGAT ( $\boldsymbol{E}$, green). The far right column shows images taken with reduced gain and saturation settings. Application of $\mathrm{Cbln} 1$ to the medium of cbln1-null cells increased the signals of VGluT1 (D) but not of VGAT (E). Scale bars: $\boldsymbol{A}$, two far left columns, $30 \mu \mathrm{m}$ (the entire images of the Purkinje cell); $\boldsymbol{A}$, three columns on the right, $\boldsymbol{C}-\boldsymbol{E}, 10 \mu \mathrm{m}$ (the enlarged view of the distal dendrites). 
When the culture was incubated with recombinant HA-Cbln1 ( $3 \mu \mathrm{g} / \mathrm{ml}$ ) from 14 to $16 \mathrm{DIV}$ for $7 \mathrm{~d}$, the intensity of synaptophysin immunoreactivity in cbln1-null Purkinje cells significantly increased $(n=24 ; p<0.0001$ ) (Fig. $1 A, B)$ and became comparable with that of the wild-type control $(n=24 ; p=0.25)$. Because Cbln1 is heavily glycosylated and secreted as a hexamer with a molecular weight of $\sim 230 \mathrm{kDa}$ (Bao et al., 2005; Iijima et al., 2007), $3 \mu \mathrm{g} / \mathrm{ml} \mathrm{HA}-\mathrm{Cb} \ln 1$ corresponded to $13.2 \mathrm{nM}$. The biological activities of the $\mathrm{Clq}$ family often depend on its ability to form a hexamer and a higher molecular weight complex via the N-terminal domain (Pajvani et al., 2003; Tsao et al., 2003). Therefore, to confirm the specificity of Cbln 1 , we examined the effect of a mutant Cbln1 (dS-Cbln1), with N-terminal two cysteine residues that were replaced with serines and could not form a hexamer (Bao et al., 2005). Application of dS-Cbln1 $(3 \mu \mathrm{g} / \mathrm{ml})$ failed to increase synaptophysin immunoreactivity in $c b \ln 1$-null Purkinje cells (relative intensity normalized to control, $0.99 \pm$ $0.03 ; n=24 ; p=0.80$ ) (Fig. $1 C$ ), indicating that the synaptogenic effect of Cbln 1 depends on its ability to form a hexamer.

The same treatment with wild-type HA-Cbln1 also increased the intensity of VGluT1, a specific marker for glutamatergic presynaptic terminals, and its colocalization with the dendrites of the Purkinje cells (relative intensity, $1.26 \pm 0.05 ; n=24 ; p<0.0001$ ) (Fig. $1 D)$. In contrast, no change was noted in the intensity of VGAT, a marker of glycine- and GABA-containing terminals, and its colocalization with the dendrites of Purkinje cells (relative intensity, $1.05 \pm 0.06 ; n=24 ; p=0.47)$ (Fig. $1 E$ ). When exogenous Cbln1 was applied to the wild-type culture, we did not observe any additional effect on the synaptophysin immunoreactivity (supplemental Fig. 2A, available at www.jneurosci.org as supplemental material), suggesting that the endogenous level of Cbln 1 in the medium was already saturated. These findings indicate that recombinant HA-Cbln 1 rapidly induced excitatoryspecific synapse formation in cultured Cbln1-null Purkinje cells.

In the mature cerebellum in vivo, VGluT1 is mainly associated with PF terminals. To examine whether the effect of HA-Cbln1 was specific to PF-Purkinje cell synapses in vitro, we quantified the intensities of the synaptophysin immunoreactivity that did not colocalize with the calbindin-positive regions in $c b \ln 1$-null cells. Outside the calbindin-positive region, the intensity of the synaptophysin immunoreactivity did not change (supplemental Fig. 2B, available at www.jneurosci.org as supplemental material). We also examined the effect of HA-Cbln1 on the synapses formed on the dendrites of parvalbumin-positive interneurons, which also receive PFs from granule cells in vivo. Unlike the Purkinje cells, the parvalbumin-positive interneurons had few dendritic branches and no spines (supplemental Fig. $2 C$, available at www.jneurosci.org as supplemental material). We found that the synaptophysin immunoreactivity that colocalized on the dendrites of the interneurons did not change with the addition of HA-Cbln1 to the medium (supplemental Fig. 2C, available at www.jneurosci.org as supplemental material). These results indicated that the effect of exogenous Cbln 1 predominantly affected the excitatory synapses that formed between the PFs and Purkinje cells in the culture.

\section{The effect of Cbln1 is transient and required for the maintenance of PF synapses in vitro}

To examine whether Cbln1 was also required for the maintenance of PF-Purkinje cell synapses in vitro, we analyzed the density of the synapses after the removal of exogenous HA-Cbln1 from the culture medium. We first incubated $c b \ln 1$-null cerebellar cells with HA-Cbln1 $(3 \mu \mathrm{g} / \mathrm{ml})$ for $7 \mathrm{~d}$ to restore the synaptic

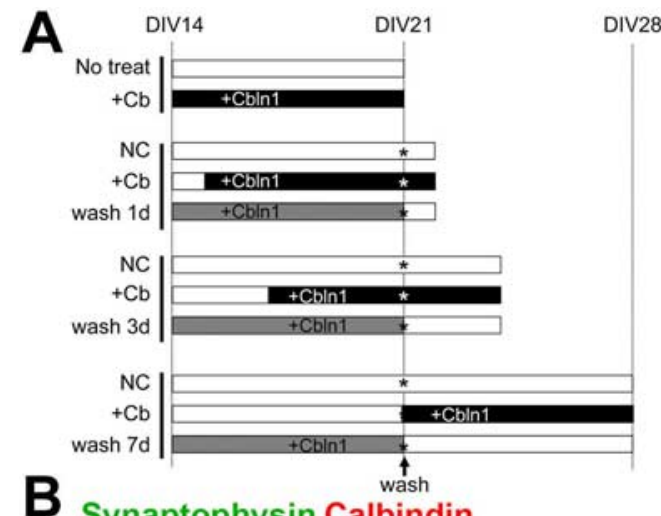

Synaptophysin Calbindin

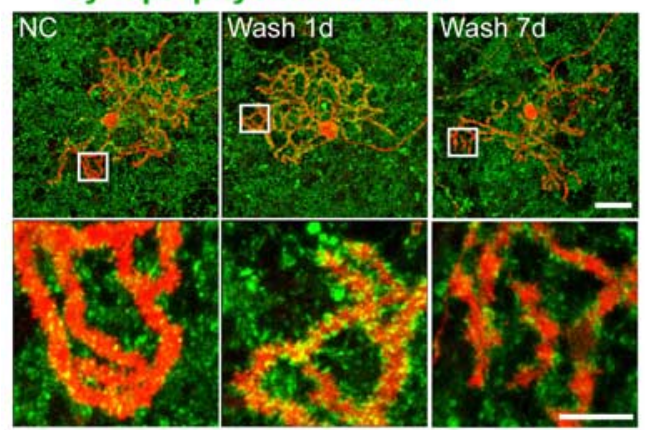

C

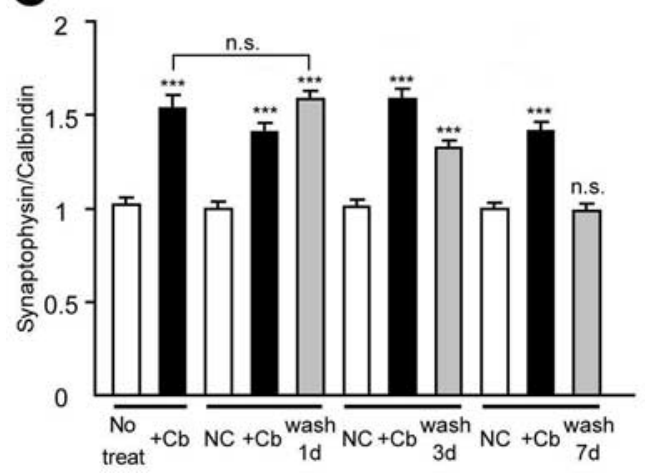

Figure 2. Continued presence of $C b \ln 1$ is necessary to maintain cbln1-null Purkinje cell synapses in vitro. $\boldsymbol{A}$, Experimental design. (bln1-null cerebellar cultures were incubated with exogenous HA-Cbln1 ( $3 \mu \mathrm{g} / \mathrm{ml}$ ) for $7 \mathrm{~d}$ from 14 DIV (gray bars). The cells were fixed on days 1 , 3, or 7 after the removal of HA-Cbln1 at 21 DIV (wash $1 \mathrm{~d}$, wash $3 \mathrm{~d}$, and wash $7 \mathrm{~d}$ ). As a negative control, the cells were incubated with medium containing no HA-Cbln1 for $7 \mathrm{~d}$ (No treat) or for indicated durations (NC, negative control; unfilled bars). As a positive control, HA-Cbln1 was added $(3 \mu \mathrm{g} / \mathrm{ml})$ to the medium at various time points ( $+\mathrm{Cb}$; filled bars). The culture medium was replaced and rinsed with the appropriate medium at 21 DIV (the asterisk indicates wash). $\boldsymbol{B}$, Representative images of distal dendrites of Purkinje cells stained with calbindin (red) and synaptophysin (green). The synaptophysin signal on the dendrites gradually decreased. Scale bars: top, $30 \mu \mathrm{m}$; bottom, $10 \mu \mathrm{m}$. C, Average intensity of synaptophysin signal at the distal dendrites of the Purkinje cells. The effect of removing HA-Cbln1 was estimated by comparing with the no-treatment control (No treat) or negative control (NC) for each group. One day after the removal of exogenous Cbln1, the signal was still comparable with the level before removal, whereas $7 \mathrm{~d}$ after the removal, the signal declined to the value of the negative control ( $n=24$ cells; 3 independent experiments; $\left.{ }^{* * *} p<0.001\right)$. n.s., No significant difference.

density on the Purkinje cells and then replaced the culture medium with one that did not contain HA-Cbln1 (Fig. 2A). One day after the removal of HA-Cbln1, the intensity of the synaptophysin immunoreactivity that colocalized with the dendrites of the Purkinje cells was still comparable with the level before removal $(n=24 ; p=0.57)$ (Fig. $2 B, C)$. Seven days after the removal of HA-Cbln1, the intensity of the synaptophysin immunoreactivity 


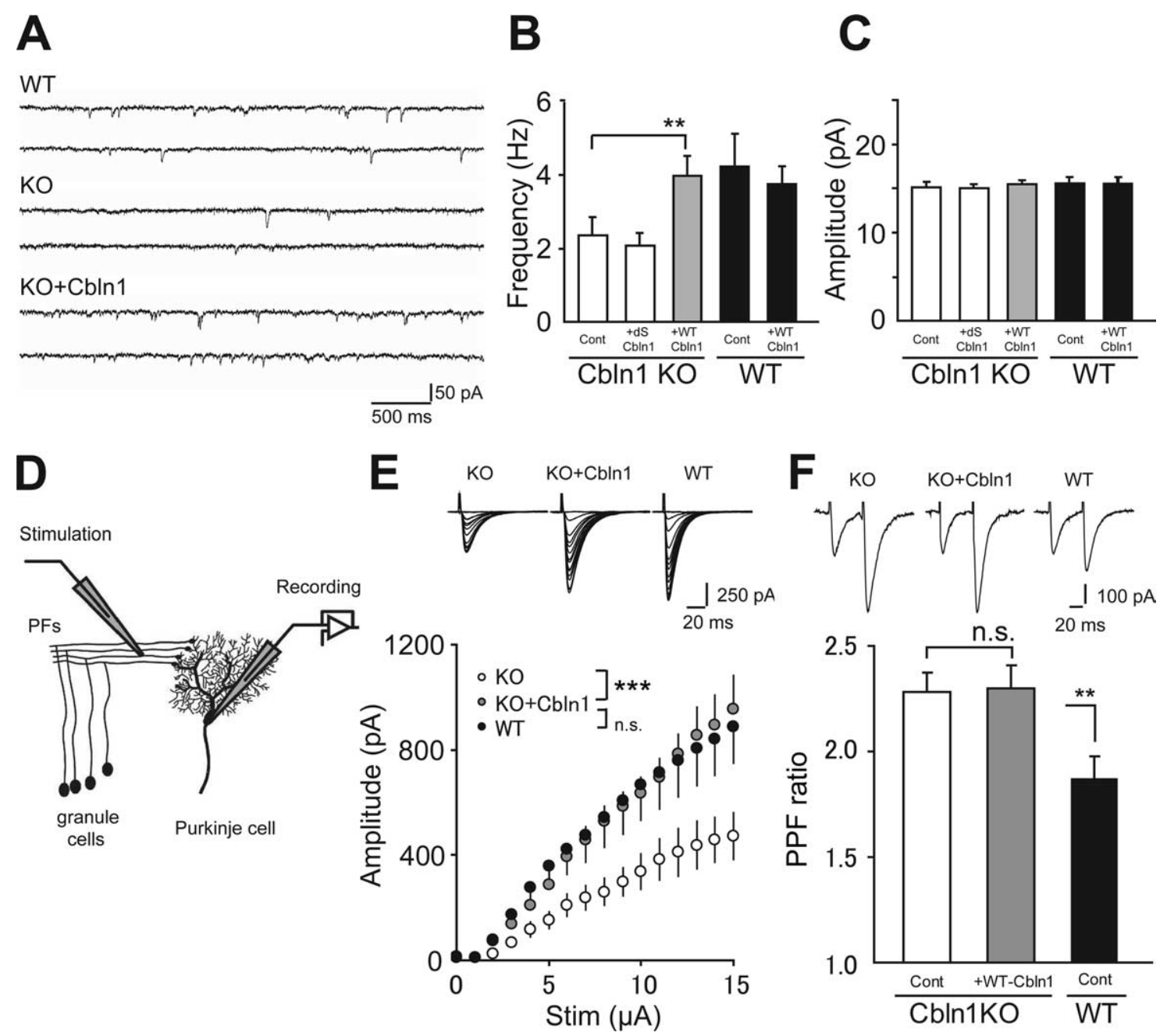

Figure 3. Formation of functional PF-Purkinje cell synapses in acute slices of $c b / n 1$-null mice after incubation with exogenous Cbln1.A-C, $m E$ EPSCs from Purkinje cells were recorded in the slices

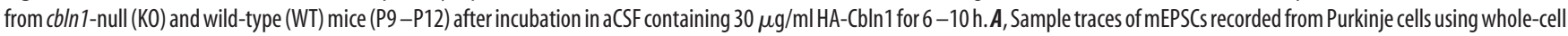
recordings. $\boldsymbol{B}$, The average frequency of the $\mathrm{mEPSC}$ in cbln 1-null cells was significantly increased by exogenous wild-type HA-Cbln1 (WT-Cbln1) and became comparable with that in the WT control. No change was observed with a mutant $\mathrm{Cb} \ln 1$ (dS-Cbln1;30 $\mu \mathrm{g} / \mathrm{ml}) .{ }^{* *} p<0.01$. C, The average amplitude of the mEPSCs was not changed by exogenous HA-Cbln1.D, Purkinje cells were whole-cell voltage clamped to record EPSCs evoked by the stimulation of PFs, the axon bundles of granule cells. Acute slices from P13 to P15 mice were treated as described above before recording. $E$, The amplitude of PF-EPSCs in cbln1-null cells increased to the wild-type level after incubation with exogenous HA-Cbln1. Insets show representative PF-EPSC traces recorded from Purkinje cells clamped at $-70 \mathrm{mV}$ in response to increasing stimulus intensities. ${ }^{* * *} p<0.001$. n.s., No significant difference. $F$, Summarized plots of the PPF ratio. The PPF ratio was defined as the amplitude of the second EPSC divided by that of the first EPSC at interpulse intervals of $50 \mathrm{~ms}$. The PPF ratio, which was increased in cbln 1-null cells, did not change with exogenous HA-Cbln1. The inset shows representative PF-EPSC traces in response to paired pulses. ${ }^{* *} p<0.01$. n.s., No significant difference.

significantly decreased and became comparable with the level in the control cultures that were not treated with HA-Cbln1 $(n=$ $24 ; p=0.77$ ) (Fig. $2 B, C$ ). In contrast, when the medium was replaced with the one that contained HA-Cbln1 on $21 \mathrm{DIV}, \mathrm{PF}$ synapses were maintained, indicating that medium exchange itself did not have any detrimental effects on the synaptophysin immunoreactivity of the Purkinje cells (Fig. 2A,C). These results indicate that the effect of exogenous Cbln 1 is transient and that continued presence of Cbln 1 is required for the maintenance of PF synapses in cultured $c b \ln 1$-null Purkinje cells.

\section{Exogenous Cbln1 induces functional excitatory synapses in acute cerebellar slices}

To examine whether new synapses induced by HA-Cbln 1 were functional, we next recorded mEPSCs from Purkinje cells using the whole-cell patch-clamp method (Fig. $3 A$ ). We adopted acute cerebellar slices prepared from young mice [postnatal day 9 (P9) to P12] to avoid variable PF innervation patterns in dissociated cultures and to achieve better space-clamp conditions. The average frequency of mEPSCs in $c b \ln 1$-null Purkinje cells $(2.35 \pm 0.50$ $\mathrm{Hz} ; n=13$ ) was significantly lower $(p<0.01)$ (Fig. $3 B)$ than that of wild-type cells $(3.99 \pm 0.52 \mathrm{~Hz} ; n=16)$, a result consistent with the reduced number of PF synapses in $c b \ln 1$-null Purkinje cells in culture (Fig. 1A). After incubation with wild-type HACbln1 $(30 \mu \mathrm{g} / \mathrm{ml} ; \sim 132 \mathrm{nM}$ ) for $6-10 \mathrm{~h}$ before recording, the frequency of mEPSCs in $c b \ln 1$-null cells was significantly higher than that of cells treated with the control medium $(3.99 \pm 0.54$ $\mathrm{Hz} ; n=13 ; p<0.01$ ) (Fig. 3B), and the difference between the wild-type and $c b \ln 1$-null Purkinje cells was no longer significant $(p=0.75)$. Incubation with dS-Cbln $1(30 \mu \mathrm{g} / \mathrm{ml})$ did not have any effect on the frequency of mEPSCs $(2.09 \pm 0.34 ; n=16 ; p=$ 0.38 ) (Fig. $3 B$ ) in $c b \ln 1$-null Purkinje cells, indicating the specific effects of wild-type HA-Cbln1. The amplitude of the mEPSCs did not change after the application of HA-Cbln1 to wild-type ( $p=$ 

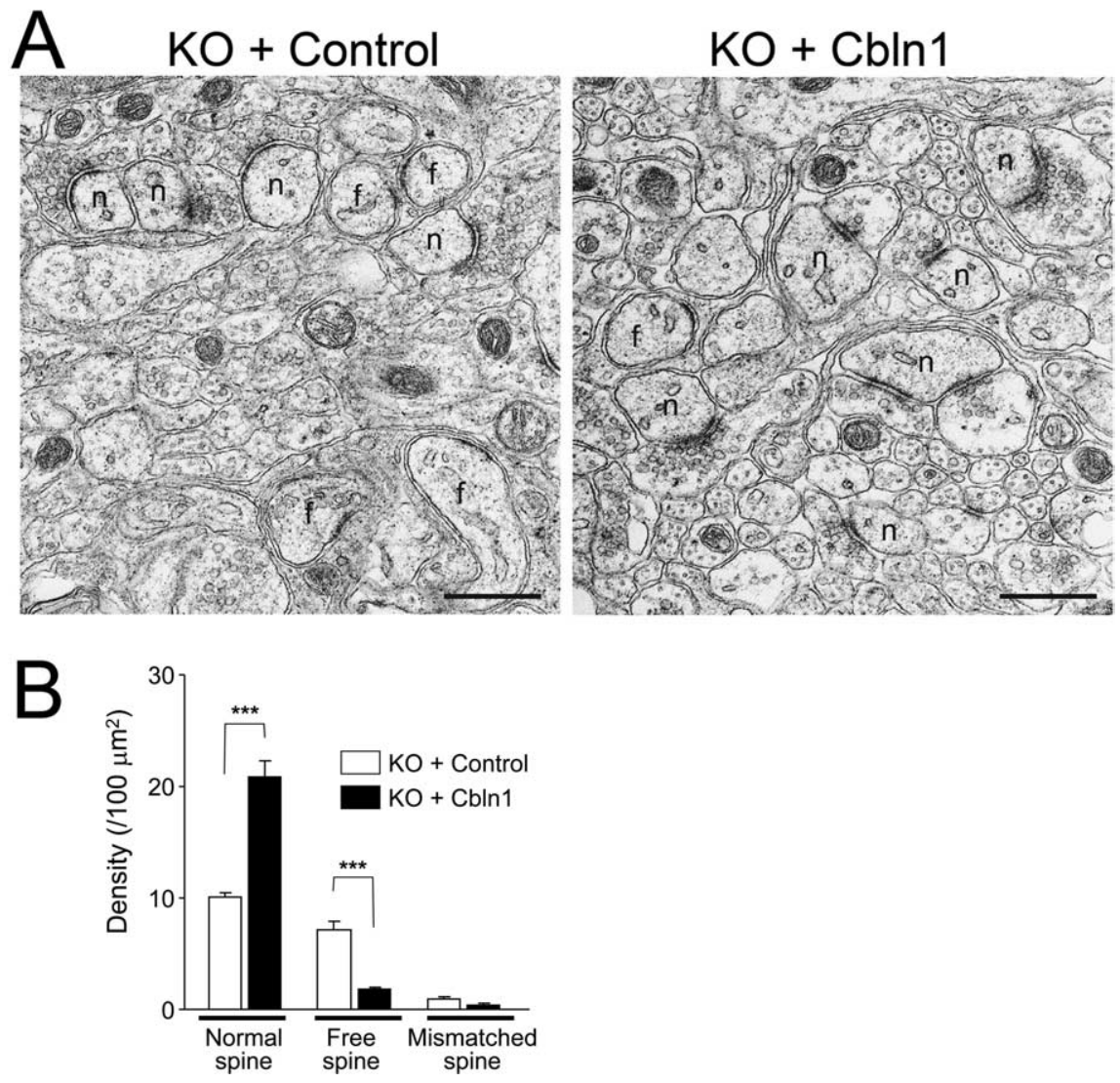

Figure 4. Anatomical recovery of PF-Purkinje cell synapses in acute slices of cbln 1-null mice after the incubation with exogenous Cbln1. A, Electron micrographs of the molecular layer of the acute cerebellar slices prepared from cbln1-mice aged P14 after incubation with $30 \mu \mathrm{g} / \mathrm{ml}$ exogenous $\mathrm{HA}$-Cbln 1 for $8 \mathrm{~h}$. In control slices, free spines (f) were observed frequently. Treatment with HA-Cbln1 significantly increased normal spines ( $\mathrm{n}$ ) and reduced the ratio of free spines. Scale bar, $500 \mathrm{~nm}$. B, Density of normal, free, and mismatched spines in cbln 1 -null acute cerebellar slices after incubation with $\mathrm{HA}-\mathrm{Cb} \ln 1$ or control medium for 8 h. $n=10-11$ sections for each treatment $\left(n=1\right.$ mouse). ${ }^{* *} p<0.001$.
Purkinje cells with HA-Cbln1 (2.29 \pm 0.11 ; $n=16 ; p=0.93$ ) (Fig. $3 F$ ). These results, together with the effect of Cbln1 on mEPSCs (Fig. 3A-C), indicate that Cbln1 primarily increased the number of functional synapses in $c b \ln 1$-null cerebellar slices in a time window of $6-10 \mathrm{~h}$.

To further confirm the effect of HACbln 1 on acute slices, we used electron microscopy to examine the ultrastructure of the PF-Purkinje cell synapses in acute slices treated with exogenous Cbln1. Indeed, we found that the anatomical abnormality in the synapses of $c b \ln 1$-null mice was markedly improved after incubation with 30 $\mu \mathrm{g} / \mathrm{ml}$ of HA-Cbln 1 for $8 \mathrm{~h}$ (Fig. 4); $>90 \%$ of the spines formed asymmetrical synapses with presynaptic terminals. In contrast, in cbln1-null slices treated with aCSF but without HA-Cbln1, only $\sim 50 \%$ of the spines contacted presynaptic terminals, and the remaining half were free spines. The effects of Cbln 1 on the electron microscopic recovery of PF synapses in acute slices were faster than those on synaptophysin immunoreactivity in dissociated Purkinje cells (supplemental Fig. 1, available at www.jneurosci.org as supplemental material); this result may be explained by the higher density of presynaptic PF terminals in the acute slices, compared with those in the dissociated cell cultures. Altogether, these findings indicate that exogenous Cbln1 induced functional as well as morphological PF synapse formation in $c b \ln 1$ null Purkinje cells in acute slices.
$0.23 ; n=16)$ and $c b \ln 1$-null $(p=0.25 ; n=13)$ Purkinje cells (Fig. 3C). No additional increase in the frequency was observed when HA-Cbln1 was applied to wild-type Purkinje cells (3.76 \pm $0.50 \mathrm{~Hz} ; n=16 ; p=0.52$ ) (Fig. $3 B$ ), which was consistent with the effect on synaptophysin immunoreactivity in cultured wildtype Purkinje cells (supplemental Fig. 2A, available at www. jneurosci.org as supplemental material). These results suggest that HA-Cbln1 rapidly increased the number of functional synapses or the release probability of preexisting synapses in $c b \ln 1$ null Purkinje cells in slices.

We next examined the effect of exogenous Cbln 1 on the amplitude of PF-EPSCs in acutely prepared slices (Fig. 3D). As reported previously (Hirai et al., 2005), the PF-EPSC amplitudes in cbln1-null Purkinje cells were consistently smaller than those in wild-type Purkinje cells ( $n=9$ cells; $p<0.0001$; two-way ANOVA) (Fig. 3E), indicating an impaired PF-Purkinje cell synaptic function. We found that incubation with HA-Cbln1 for 6-10 h significantly increased the PF-EPSC amplitudes in $c b \ln 1$ null cells $(n=9 ; p<0.0001$; two-way ANOVA) (Fig. $3 E)$. The probability of presynaptic transmitter release was assessed by measuring the paired-pulse facilitation (PPF) of the PF-EPSCs. We found that the PPF ratio at interpulse intervals of $50 \mathrm{~ms}$ was significantly higher in $c b l n 1$-null Purkinje cells $(2.28 \pm 0.09 ; n=$ $16 ; p<0.01)$ (Fig. 3F) than in wild-type cells $(1.87 \pm 0.09 ; n=$ $16)$, reflecting a lower presynaptic release probability. The increased PPF ratio was not rescued by the incubation of $c b \ln 1$-null
Cbln1 restores PF synapses and motor performance in adult cbln1-null mice in vivo

Finally, to examine the function of Cbln 1 in mature neurons in vivo, we applied HA-Cbln1 to adult cbln1-null mice. HA-Cbln1 ( $1 \mu \mathrm{g} / \mathrm{g}$ body weight) was injected into the subarachnoid supracerebellar space above the cerebellar vermis of $c b \ln 1$-null mice aged P42-P54. Immunohistochemical analysis with anti-HA antibody after $24 \mathrm{~h}$ of injection revealed the injected HA-Cbln 1 to be distributed widely in the cerebellar cortex of all lobules with a gradient from the injected site (Fig. 5A). With higher magnification, the signal showed a punctate pattern over calbindin-positive Purkinje-cell spines in the molecular layer (Fig. 5A). Immunohistochemical analysis of the sagittal section of the whole brain revealed that the injected Cbln 1 was restricted to the cerebellum (supplemental Fig. 3A, available at www.jneurosci.org as supplemental material). The immunoreactivity significantly decreased with time after the injection (supplemental Fig. $3 B$, available at www.jneurosci.org as supplemental material), and the signal had decreased to the background level on day 7. Immunoblot analysis using anti-HA and anti-Cbln1 antibody indicated that the injected HA-Cbln1 was present in the membrane fraction (P2) of the whole cerebellum (Fig. 5B). Twenty-four hours after the injection, we found that the protein amount of injected HA-Cbln 1 in the P2 fraction was comparable with that of endogenous Cbln 1 found in wild-type mice (relative amount normalized by actin, $0.88 \pm 0.11 ; n=3$ mice; $p=0.69$ ). Consistent with the immu- 
A

Calbindin HA-Cbln1

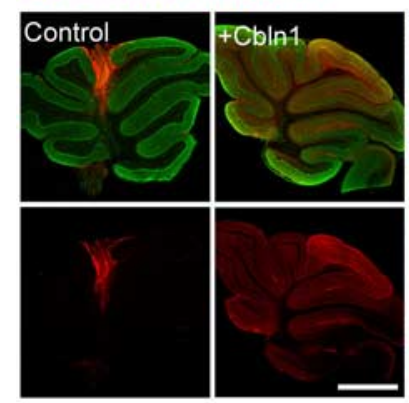

C

\section{$\mathrm{KO}$ before injection}

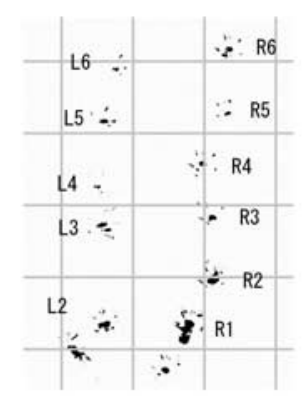

\section{B}

(a)

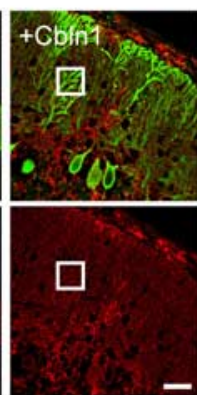

enlarged

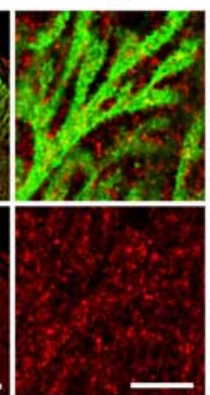

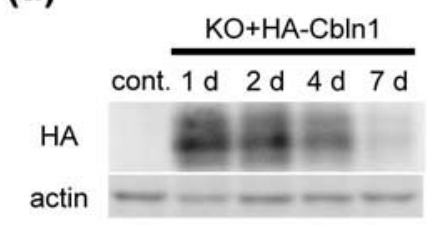

(b)

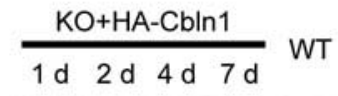

Cbln1 (c)

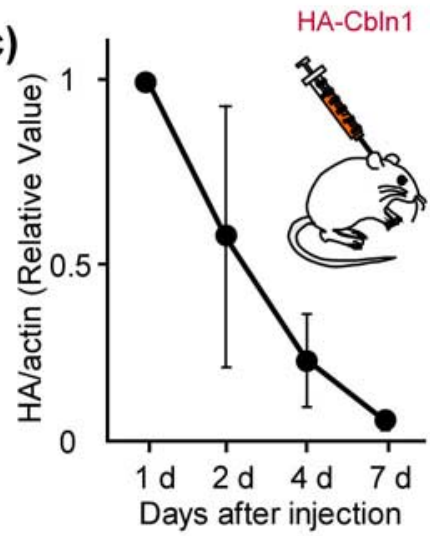

D

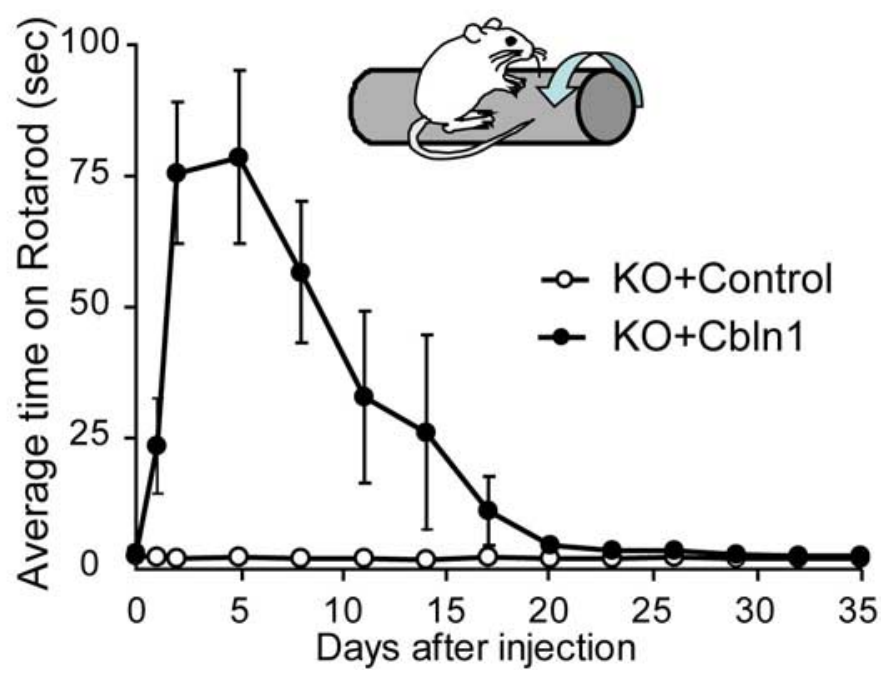

Figure 5. Improvement of cerebellar ataxia in adult cbln1-null mice after the subarachnoidal injection of Cbln1. $A$, Distribution of injected Cbln1, stained with anti-HA antibody (red), in the cerebellum at $24 \mathrm{~h}$ after injection. Purkinje cells were stained with calbindin (green). The injected Cbln1 was localized in all the cerebellar lobules. Enlarged images show the punctate signal of HA-Cbln1 localized on the dendrites of Purkinje cells. Scale bars: two far left columns, $1 \mathrm{~mm}$; third column from the left, $30 \mu \mathrm{m}$; fourth column, $10 \mu \mathrm{m}$. $\boldsymbol{B}$, Injected Cbln1 from the P2 fraction of the whole cerebellum was detected using immunoblotting and an antibody against $\mathrm{HA}(\boldsymbol{a})$ or $\mathrm{Cb} \ln 1(\boldsymbol{b})$ at 1, 2, 4, and $7 \mathrm{~d}$ after the injection. The signal in $\boldsymbol{a}$ was normalized with that of actin and further normalized to the value at $1 \mathrm{~d}$ after the injection (c). The injected HA-Cbln 1 level decreased to $<10 \%$ on day 7 ( $n=3$ mice). $\boldsymbol{C}$, Representative gait pattern of a cbln 1 -null mouse before and $2 \mathrm{~d}$ after the injection. The hindpaws were marked with black paint. The irregular, shortened gait skips were markedly improved after the injection of Cbln1. L, Left paw; R, right paw. Numbers indicate step counts. $D$, Results on the rotarod test after the injection of Cbln1 medium (KO+Cbln1) or the control medium (KO + control). The average time on the rotarod at $20 \mathrm{rpm}$ was calculated from four trials ( $n=4$ mice).

nohistochemical analysis (supplemental Fig. 3B, available at www.jneurosci.org as supplemental material), the amount of injected HA-Cbln 1 on day 7 had decreased to $\sim 7 \%$ of that measured at $24 \mathrm{~h}$ after injection (Fig. 5B). These findings indicate that the injected HA-Cbln 1 preferentially bound to the cerebellum and remained in the cell membrane for several days.

A single injection of HA-Cbln1 exerted a remarkable effect on the locomotive performance of adult $c b \ln 1$-null mice (supplemental movies, available at www.jneurosci.org as supplemental material). Before injection, the gait pattern was highly abnormal, with irregular short footsteps (Fig. 5 C). Significant improvement was observed within $24 \mathrm{~h}$, and at $2 \mathrm{~d}$ after the injection, the animal's gait became apparently normal (Fig. $5 C$ ). To evaluate the level of ataxia quantitatively, the mice were tested using a rod that rotated at 10 or $20 \mathrm{rpm}$; each mouse was examined four times per day at various time points before and after the injection of $\mathrm{HA}-\mathrm{Cb} \ln 1$. The average retention time on the rotarod at $20 \mathrm{rpm}$ improved within $24 \mathrm{~h}$ after the injection (Fig. 5D) (average time, $3.1 \pm 0.3 \mathrm{~s}$ before injection and $23.5 \pm 0.9 \mathrm{~s}$ at $24 \mathrm{~h}$ after injection; $n=4$ mice). The time on the rotarod reached a peak at $2 \mathrm{~d}$ after the injection $(75.6 \pm 13.5 \mathrm{~s} ; p<0.01$, paired $t$ test $)$. The effect lasted until day 4 , but the performance gradually began to worsen after day 7. Three weeks after the injection, the animals were highly ataxic once again and were unable to stay on the rotarod for more than a few seconds $(4.4 \pm 1.3 \mathrm{~s} ; p=0.32)$. No significant effect was observed in mice injected with the control medium. The time course of the behavioral recovery after a single injection of HA-Cbln 1 was primarily consistent with that of the HA-Cbln1 protein levels in the cerebellum (Fig. $5 B$ ).

To examine the morphological basis of the behavioral recovery, we next performed an electron microscopic analysis on cbln1-null cerebellum injected with HA-Cbln1. Although the density of the total spines remained constant throughout the experiment, we observed drastic changes in the ratio of normal spines contacted with PF terminals and free spines lacking a presynaptic partner (Fig. 6A, B; Table 1). The percentage of normal spines increased within $1 \mathrm{~d}(75.3 \pm 1.3 \% ; n=3$ mice; $p<0.0001$, compared with $c b \ln 1$-null mice without treatment) and peaked at day $4(90.7 \pm 1.3 \% ; p<0.0001)$. Thereafter, the percentage of normal spines started to decline, reaching approximately one- 
A

$\mathrm{KO}+$ Control $2 \mathrm{~d}$

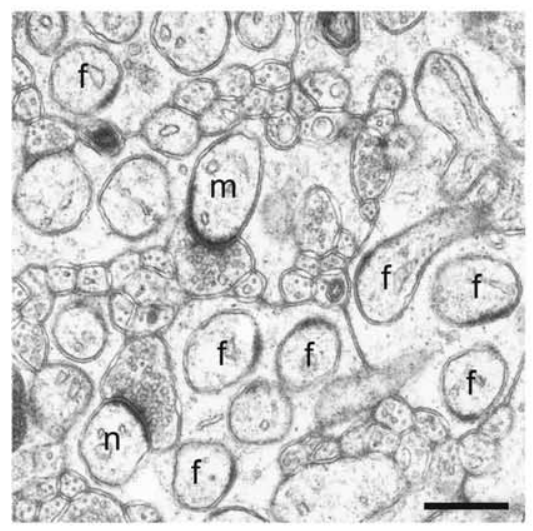

$\mathrm{KO}+\mathrm{HA}-\mathrm{Cb} \ln 12 \mathrm{~d}$

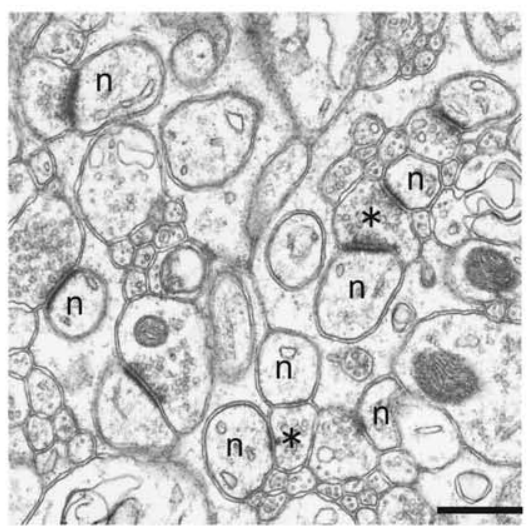

$\mathrm{KO}+\mathrm{HA}-\mathrm{Cb} \ln 135 \mathrm{~d}$

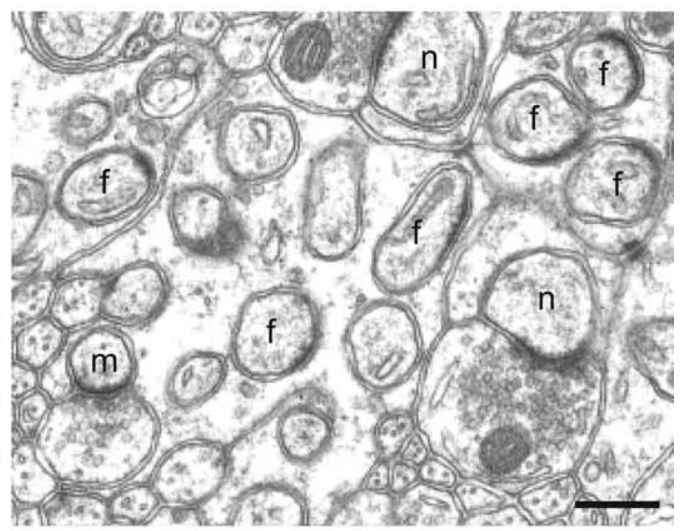

C

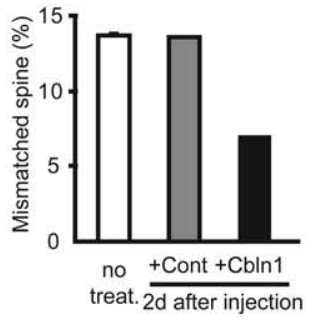

Figure 6. Complete but transient structural restoration of PF-Purkinje cell synapses in cbln1-null mice by subarachnoidal injection of Cbln1. $A$, Electron micrographs of the molecular layer in cbln 1-null mice aged P42-P54 at $2 \mathrm{~d}$ after the injection of either control or HA-Cbln1 and at $35 \mathrm{~d}$ after the injection of HA-Cbln1. In control mice, free spines ( $\mathrm{f}$ ) and mismatched spines ( $\mathrm{m}$ ) were found frequently. Two days after the injection of HA-Cbln1, the number of normal spines $(n)$ had increased, and PF terminals that were in contact with multiple spines $(*)$ were observed frequently. Thirty-five days after the injection, the number of normal spines had decreased to the original level. $\boldsymbol{B}$, Percentage of normal and free spines in cbln 1 -null mice at 1,2,4,7, 12, and $35 \mathrm{~d}$ after the injection of HA-Cbln1 ( $n=3$ mice). The effect of Cbln1 was compared with that in age-matched cbln1-null mice that did not receive treatment (no treat.). ${ }^{*} p<0.05 ;{ }^{\#} p<0.001$; ${ }^{\# \#} p<0.0001$. C, Percentage of mismatched spines estimated using serial section electron microscopy in cbln1-null mice without treatment ( $n=3$ mice) and $2 \mathrm{~d}$ after the injection of either the control or Cbln1 medium ( $n=1$ mouse). The number of mismatched spines decreased with the injection of HA-Cbln1.

Table 1. Density of spines (per $100 \mu \mathrm{m}^{2}$ ) after Cbln1 injection

\begin{tabular}{|c|c|c|c|c|c|c|c|c|c|}
\hline \multirow[b]{2}{*}{ Days after treatment } & \multirow[b]{2}{*}{ No treatment } & \multicolumn{6}{|l|}{$+C b \ln 1$} & \multicolumn{2}{|l|}{+ Control } \\
\hline & & $1 d$ & $2 d$ & $4 d$ & $7 d$ & $12 \mathrm{~d}$ & $35 d$ & $2 d$ & $12 d$ \\
\hline Normal spine & $8.2 \pm 0.7$ & $33.4 \pm 1.5^{* *}$ & $32.5 \pm 1.2^{* * *}$ & $33.1 \pm 1.8^{* *}$ & $24.5 \pm 1.6^{* *}$ & $14.6 \pm 1.3^{*}$ & $8.6 \pm 0.7$ & $8.2 \pm 0.5$ & $8.8 \pm 0.5$ \\
\hline Free spine & $27.3 \pm 1.9$ & $9.5 \pm 0.8^{* *}$ & $4.7 \pm 0.6^{* * *}$ & $2.3 \pm 0.3^{* *}$ & $9.4 \pm 0.6^{* *}$ & $21.7 \pm 1.2^{*}$ & $26.8 \pm 1.0$ & $24.6 \pm 1.0$ & $29.4 \pm 1.0$ \\
\hline Total & $38.5 \pm 2.8$ & $44.5 \pm 2.1$ & $39.3 \pm 1.8$ & $36.6 \pm 2.1$ & $37.4 \pm 1.9$ & $41.1 \pm 1.6$ & $39.8 \pm 1.7$ & $37.9 \pm 1.3$ & $41.9 \pm 1.2$ \\
\hline
\end{tabular}

The densities of the normal and free spines were evaluated using the Mann-Whitney $U$ test, whereas those of the total spines were evaluated using the $t$ test. Values are mean \pm SEM. ${ }^{*} p<0.05$; ${ }^{* *} p<0.001 ;{ }^{* * *} p<0.0001$.

third by $12 \mathrm{~d}$ and returning to the original value at 1 month after the injection $(21.3 \pm 1.1 \%$; $p=0.34)$ (Fig. $6 B)$. The reliability of estimating the spine density using plane sections was confirmed by performing a serial section analysis at $2 \mathrm{~d}$ after the injection. The percentages of free spines that were estimated using plane sections were $64.8 \pm 1.4$ and $11.4 \pm 1.3 \%$ after the injection of the control and HA-Cbln1, respectively; using serial sections, the percentages were 70.9 and $8.9 \%$, respectively. These findings indicate that a single injection of HA-Cbln1 rapidly and almost completely restored the ultrastructures of PF-Purkinje cell synapses within $2 \mathrm{~d}$ (Fig. 6).

In $c b \ln 1$-null cerebellum, spines that have PSDs longer than the respective active zones, which are referred to as "mismatched spines," are observed frequently (Hirai et al., 2005). Indeed, using serial section electron microscopy, we confirmed that $13.6 \pm$ $0.1 \%$ of the total spines ( $n=3$ mice) were mismatched with the active zones in $c b \ln 1$-null mice, as reported previously (Hirai et al., 2005). However, $2 \mathrm{~d}$ after the injection of HA-Cbln1, the percentage decreased to $7 \%$, whereas no effect was observed after the injection of the control medium (Fig. 6C). These results indicate that, like free spines, mismatched spines in the $c b \ln 1$-null cerebellum were rescued by HA-Cbln 1 .

Interestingly, although a single PF terminal usually innervates a single Purkinje cell spine in wild-type cerebellum (Rhyu et al., 1999), we often found PF terminals that innervated two or even more spines in $c b \ln 1$-null Purkinje cells treated with HA-Cbln1 (Fig. 6A). The density of such spines reached a peak on day 4 (density in nontreated control, $0.12 \pm 0.09 / 100 \mu \mathrm{m}^{2} ; 4 \mathrm{~d}$ after 

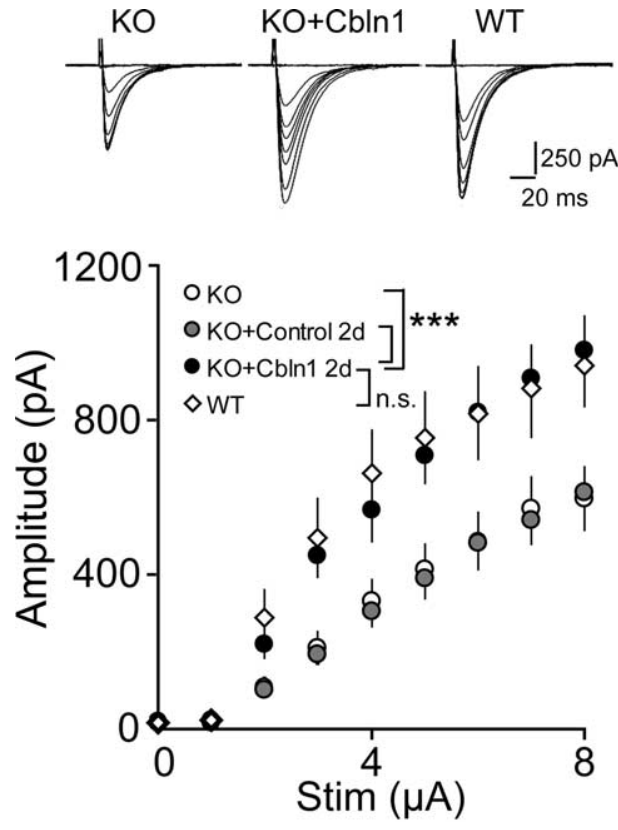

Figure 7. Functional restoration of PF-Purkinje cell synapses in cbln 1-null mice by the injection of Cbln1. Two days after the injection, PF-EPSCs were recorded from Purkinje cells using the whole-cell patch-clamp technique. The input- output relationship of PF-EPSCs in cbln1-null cells became similar to those in wild-type cells after a single injection of HA-Cbln1. The injection of control medium had no effect. ${ }^{* * *} p<0.001$.

HA-Cbln $1,1.74 \pm 0.23 / 100 \mu \mathrm{m}^{2} ; p<0.0001$, Mann-Whitney $U$ test) and declined by day $12\left(0.35 \pm 0.07 / 100 \mu \mathrm{m}^{2} ; p=0.13\right)$. Similar phenomena have been observed during normal development (Kurihara et al., 1997) and in certain cerebellar mutant mice (Rhyu et al., 1999), suggesting that Cbln1 may underlie these pathological and physiological structural changes at synapses.

Finally, we performed an electrophysiological analysis on acute cerebellar slices prepared from $c b \ln 1$-null mice $2 \mathrm{~d}$ after the injection of HA-Cbln1. We found that the amplitude of PFEPSCs was significantly increased in mice injected with Cbln 1 ( $n=8$ cells from 3 mice; $p<0.0001$, two-way ANOVA) (Fig. 7) and became comparable with that of wild-type Purkinje cells $(p=0.57)$. Altogether, these findings indicate that Cbln 1 could restore morphological and functional PF synapses and, as a result, motor performance in adult cbln1-null mice in vivo.

\section{Discussion \\ Cbln1 regulates the maintenance and the formation of $\mathrm{PF}$ synapses in adult cerebellum}

Synapse formation during development has been studied extensively in the past (Umemori et al., 2004; Tada and Sheng, 2006; McAllister, 2007). However, little is known about how synaptic structure is maintained and regulated in the adult brain. Recently, Cbln 1 was shown to be indispensable for the normal development of PF-Purkinje cell synapses in vivo (Hirai et al., 2005). Here, we found that treatment with HA-Cbln 1 almost completely restored PF synapses in mature cbln1-null cerebellum in vitro (Figs. 1, 3) and in vivo (Fig. 6). Importantly, the effects of Cbln1 treatment were transient both in vitro (Fig. 2) and in vivo (Figs. 5, 6). These findings indicate that Cbln 1 is necessary not only for synapse formation but also for the maintenance of mature PFPurkinje cell synapses.

Interestingly, ultrastructural abnormalities in $c b \ln 1$-null mice are shared by mice that lack the gene encoding the orphan $\delta 2$ glutamate receptor (GluR $\delta 2)$, which is expressed selectively in Purkinje cells (Kashiwabuchi et al., 1995; Lalouette et al., 2001). Indeed, ablation of the GluR $\delta 2$ gene in adult cerebellum using an inducible recombinase also resulted in the gradual loss of normal PF synapses and an increase in spines that had mismatched PSDs (Takeuchi et al., 2005). Because ablation of the gene took as long as 8 weeks to achieve an $80 \%$ reduction in the GluR $\delta 2$ protein level (Takeuchi et al., 2005), a direct comparison of the roles of GluR $\delta 2$ and Cbln 1 is difficult. Nevertheless, these results indicate that like Cbln1, which is expressed in granule cell presynapses, GluR $\delta 2$, which is expressed in Purkinje cell postsynapses, may be engaged in a common signaling pathway required for the maintenance of PF synapses in adults. Although the site of action of Cbln 1 is unknown, the rapid and transient effects of Cbln1 suggest that it may act like a transsynaptic cell adhesion molecule that holds together presynaptic and postsynaptic elements, including GluR $\delta 2$. Additional analysis of the detailed molecular mechanism underlying Cbln1-induced synaptogenesis is warranted.

A recent study using two-photon microscopy showed that neither the spine shape nor the spine density changed after longterm synaptic plasticity was induced in acute cerebellar slices in vitro (Sdrulla and Linden, 2007). In contrast, dynamic structural changes were observed in the neocortex in vivo (Grutzendler et al., 2002; Trachtenberg et al., 2002) and in hippocampal slices in vitro (Matsuzaki et al., 2004). Similarly, a reduction of neuronal activity by the injection of an AMPA receptor antagonist or tetrodotoxin induced transient presynaptic and postsynaptic structural changes at PF synapses in adult Purkinje cells in vivo (Cesa et al., 2007). Furthermore, acrobatic motor learning increased the density of PF synapses (Black et al., 1990) and induced the formation of multiple PF synapses (two postsynaptic contacts at a single presynaptic varicosity) in the adult rat cerebellum (Federmeier et al., 2002), a similar finding to our present result (Fig. $6 A$ ). These findings suggest that PF-Purkinje cell synapses may also undergo dynamic structural changes in adult cerebellum, and that Cbln 1 might be involved in the regulation of such processes. Nevertheless, exogenous Cbln 1 did not cause further synaptogenesis in wild-type cerebellum (Fig. $3 B, C$ ) (supplemental Fig. 2A, available at www.jneurosci.org as supplemental material). The lack of effects of exogenous Cbln 1 may be explained by saturated concentrations of endogenous Cbln 1 in wild-type cerebellum (Fig. 5B). Because exogenous Cbln1 rapidly induced synaptogenesis in adult cbln1-null cerebellum, previous reduction of endogenous Cbln1 expression might be necessary before Cbln 1 could induce structural changes at synapses. Additional studies are necessary to clarify the role of Cbln 1 in the regulation of activity-dependent structural plasticity in adult wild-type cerebellum.

Cbln1 induced rapid synaptogenesis both in vitro and in vivo In cultured hippocampal cells, the formation of axodendritic contact triggers the assembly of presynaptic and postsynaptic molecules on the time scale of minutes to hours (Friedman et al., 2000; Okabe et al., 2001). However, further development of complete ultrastructure (Ahmari and Smith, 2002) and mature electrophysiological properties is thought to be a more prolonged process requiring several days (McAllister, 2007). Similarly, a combination of two-photon imaging and serial section electron microscopy of adult barrel cortex in vivo has shown recently that a mature synapse develops a few days after the appearance of a new spine (Knott et al., 2006). In contrast, the application of exogenous HA-Cbln1 induced a significant increase in functional 
synapses in P14 cbln1-null acute slices within $8 \mathrm{~h}$ and in adult cbln1-null cerebellum in vivo within $2 \mathrm{~d}$. Therefore, the time course of synaptogenesis induced by HA-Cbln 1 in vitro and in vivo was exceptionally rapid.

Several factors may have contributed to the rapid effects of HA-Cbln1. First, the effect of homomeric HA-Cbln 1 may be more potent than endogenous Cbln 1 , which is partly secreted as a heteromer complex with Cbln3 (Bao et al., 2006; Iijima et al., 2007). However, cbln3-null mice did not show any apparent morphological or behavioral abnormalities (Bao et al., 2006), and the amount of Cbln3 secreted in the cerebellar culture medium was much less than that of Cbln1 (Iijima et al., 2007). These previous findings indicate that endogenous Cbln 1 may exist mostly as a homomer. Second, structural or biochemical abnormalities in cbln1-null cerebellum may have contributed to the rapid effects of exogenous HA-Cbln1. However, we found that the protein amount of endogenous Cbln 1 in the $\mathrm{P} 2$ fraction of wild-type cerebellum was comparable with that of injected HA-Cbln1 in cbln1-null cerebellum (Fig. 5B). Therefore, we consider that the rapid synaptogenic effects of HA-Cbln1 on $c b \ln 1$-null Purkinje cells most likely reflect an intrinsic signaling mechanism.

In the hippocampus and in the neocortex, the differentiation of dendritic spines and presynaptic boutons are highly correlated (Okabe et al., 2001). In contrast, the spines of Purkinje cells are formed in the absence of nearby PF terminals (Sotelo, 1975; Bravin et al., 1999; Cesa and Strata, 2005; Morando et al., 2005). Indeed, dendritic spines are maintained as "free spines" without any attached PF terminals in adult GluR $\delta 2$-null cerebellum (Kashiwabuchi et al., 1995; Kurihara et al., 1997; Hirai et al., 2005). Similarly, the number of postsynaptic spines remained constant in $c b \ln 1$-null cerebellum before and after the administration of HA-Cbln1 (Table 1). Therefore, to form new synapses at PF-Purkinje cell synapses, Cbln1 may not have to induce new spines but assemble PF terminals onto existing postsynaptic structures. These findings suggest that the rapid synaptogenic effects of Cbln1 may reflect its role in the assembly of existing presynaptic and postsynaptic structures.

In contrast to the rapid induction of PF synapse formation by HA-Cbln1, our results in vivo showed that the detachment of PFs from the spines of Purkinje cells occurs much more slowly after the loss of HA-Cbln1 (Fig. 6C). The amount of HA-Cbln1 in the P2 fraction (Fig. 5B) and the HA-Cbln1 immunoreactivity in the molecular layer on day 4 (supplemental Fig. 3B, available at www.jneurosci.org as supplemental material) were already approximately one-quarter of the values on day 1, but the percentage of normal PF synapses on day 4 was $>90 \%$. Such delayed synaptic losses suggest that a threshold concentration of Cbln 1 may be necessary to maintain normal synapses. This may also explain why HA-Cbln 1 did not further induce synapse formation in wild-type Purkinje cells. The difference in the time course between the loss and recovery of the synapses also suggests a difference in the molecular mechanisms underlying these two processes.

\section{Cbln1 as a new antegrade presynaptic organizer}

Molecules involved in the differentiation of synapses are classified into presynaptic and postsynaptic organizers (Fox and Umemori, 2006). At present, five presynaptic organizers have been identified: Wnt-7a (Hall et al., 2000), neuroligin (Chih et al., 2005), SynCAM (Biederer et al., 2002), EphB (Kayser et al., 2006), and FGF22 (Umemori et al., 2004). All of these factors are derived from target postsynaptic cells and act as retrograde organizers to induce the clustering of synaptic vesicles and exocytosis and en- docytosis machinery near active zones (Fox and Umemori, 2006). Similarly, Cbln 1 rapidly induced the accumulation of PF terminals on the preexisting spines of $c b \ln 1$-null Purkinje cells. Therefore, although the primary site of the actions of Cbln 1 remains unclear, Cbln 1 is a robust presynaptic organizer, even if it acts indirectly. Unlike known retrograde presynaptic organizers, Cbln 1 is a unique antegrade presynaptic organizer produced and secreted from presynaptic granule cells (Hirai et al., 2005).

Cbln 1 and other family members (Cbln2 and Cbln4) are expressed in various regions of the developing and mature brain (Wada and Ohtani, 1991; Pang et al., 2000; Miura et al., 2006). In addition, C1q, a prototype member of the C1q/TNF $\alpha$ superfamily, is expressed in developmental CNS synapses (Stevens et al., 2007) and is involved in normal and pathological synapse elimination processes. Similarly, a significant decrease in the Cbln1related peptide concentration has been reported for certain neurological disorders (Mizuno et al., 1995). Because our findings imply the therapeutic potential of exogenous Cbln1, understanding the role of Cbln 1 will be of great benefit for unraveling the synaptic integrity underlying physiological and pathological conditions in the adult brain.

\section{References}

Ahmari SE, Smith SJ (2002) Knowing a nascent synapse when you see it Neuron 34:333-336.

Aoto J, Ting P, Maghsoodi B, Xu N, Henkemeyer M, Chen L (2007) Postsynaptic ephrinB3 promotes shaft glutamatergic synapse formation. J Neurosci 27:7508-7519.

Bao D, Pang Z, Morgan JI (2005) The structure and proteolytic processing of Cbln1 complexes. J Neurochem 95:618-629.

Bao D, Pang Z, Morgan MA, Parris J, Rong Y, Li L, Morgan JI (2006) Cbln1 is essential for interaction-dependent secretion of Cbln3. Mol Cell Biol 26:9327-9337.

Biederer T, Sara Y, Mozhayeva M, Atasoy D, Liu X, Kavalali ET, Sudhof TC (2002) SynCAM, a synaptic adhesion molecule that drives synapse assembly. Science 297:1525-1531.

Black JE, Isaacs KR, Anderson BJ, Alcantara AA, Greenough WT (1990) Learning causes synaptogenesis, whereas motor activity causes angiogenesis, in cerebellar cortex of adult rats. Proc Natl Acad Sci USA $87: 5568-5572$.

Bravin M, Morando L, Vercelli A, Rossi F, Strata P (1999) Control of spine formation by electrical activity in the adult rat cerebellum. Proc Natl Acad Sci USA 96:1704-1709.

Cesa R, Strata P (2005) Axonal and synaptic remodeling in the mature cerebellar cortex. Prog Brain Res 148:45-56.

Cesa R, Scelfo B, Strata P (2007) Activity-dependent presynaptic and postsynaptic structural plasticity in the mature cerebellum. J Neurosci 27:4603-4611.

Chih B, Engelman H, Scheiffele P (2005) Control of excitatory and inhibitory synapse formation by neuroligins. Science 307:1324-1328.

Federmeier KD, Kleim JA, Greenough WT (2002) Learning-induced multiple synapse formation in rat cerebellar cortex. Neurosci Lett 332:180-184.

Fox MA, Umemori H (2006) Seeking long-term relationship: axon and target communicate to organize synaptic differentiation. J Neurochem 97:1215-1231.

Friedman HV, Bresler T, Garner CC, Ziv NE (2000) Assembly of new individual excitatory synapses: time course and temporal order of synaptic molecule recruitment. Neuron 27:57-69.

Furuya S, Makino A, Hirabayashi Y (1998) An improved method for culturing cerebellar Purkinje cells with differentiated dendrites under a mixed monolayer setting. Brain Res Brain Res Protoc 3:192-198.

Grutzendler J, Kasthuri N, Gan WB (2002) Long-term dendritic spine stability in the adult cortex. Nature 420:812-816

Hall AC, Lucas FR, Salinas PC (2000) Axonal remodeling and synaptic differentiation in the cerebellum is regulated by WNT-7a signaling. Cell 100:525-535.

Hirai H, Launey T, Mikawa S, Torashima T, Yanagihara D, Kasaura T, Miyamoto A, Yuzaki M (2003) New role of delta2-glutamate receptors in 
AMPA receptor trafficking and cerebellar function. Nat Neurosci 6:869-876.

Hirai H, Pang Z, Bao D, Miyazaki T, Li L, Miura E, Parris J, Rong Y, Watanabe M, Yuzaki M, Morgan JI (2005) Cbln1 is essential for synaptic integrity and plasticity in the cerebellum. Nat Neurosci 8:1534-1541.

Iijima T, Miura E, Matsuda K, Kamekawa Y, Watanabe M, Yuzaki M (2007) Characterization of a transneuronal cytokine family Cbln-regulation of secretion by heteromeric assembly. Eur J Neurosci 25:1049-1057.

Inamura M, Itakura M, Okamoto H, Hoka S, Mizoguchi A, Fukazawa Y, Shigemoto R, Yamamori S, Takahashi M (2006) Differential localization and regulation of stargazin-like protein, gamma- 8 and stargazin in the plasma membrane of hippocampal and cortical neurons. Neurosci Res 55:45-53.

Jensen FE, Harris KM (1989) Preservation of neuronal ultrastructure in hippocampal slices using rapid microwave-enhanced fixation. J Neurosci Methods 29:217-230.

Kashiwabuchi N, Ikeda K, Araki K, Hirano T, Shibuki K, Takayama C, Inoue Y, Kutsuwada T, Yagi T, Kang Y, Aizawa S, Mishina M (1995) Impairment of motor coordination, Purkinje cell synapse formation, and cerebellar long-term depression in GluR delta 2 mutant mice. Cell 81:245-252.

Kayser MS, McClelland AC, Hughes EG, Dalva MB (2006) Intracellular and trans-synaptic regulation of glutamatergic synaptogenesis by EphB receptors. J Neurosci 26:12152-12164.

Kishore U, Gaboriaud C, Waters P, Shrive AK, Greenhough TJ, Reid KB, Sim RB, Arlaud GJ (2004) C1q and tumor necrosis factor superfamily: modularity and versatility. Trends Immunol 25:551-561.

Knott GW, Holtmaat A, Wilbrecht L, Welker E, Svoboda K (2006) Spine growth precedes synapse formation in the adult neocortex in vivo. Nat Neurosci 9:1117-1124.

Kurihara H, Hashimoto K, Kano M, Takayama C, Sakimura K, Mishina M, Inoue Y, Watanabe M (1997) Impaired parallel fiber $\rightarrow$ Purkinje cell synapse stabilization during cerebellar development of mutant mice lacking the glutamate receptor $\delta 2$ subunit. J Neurosci 17:9613-9623.

Lalouette A, Lohof A, Sotelo C, Guenet J, Mariani J (2001) Neurobiological effects of a null mutation depend on genetic context: comparison between two hotfoot alleles of the delta- 2 ionotropic glutamate receptor. Neuroscience 105:443-455.

Matsuda S, Kamiya Y, Yuzaki M (2005) Roles of the N-terminal domain on the function and quaternary structure of the ionotropic glutamate receptor. J Biol Chem 280:20021-20029.

Matsuzaki M, Honkura N, Ellis-Davies GC, Kasai H (2004) Structural basis of long-term potentiation in single dendritic spines. Nature 429:761-766.

McAllister AK (2007) Dynamic aspects of CNS synapse formation. Annu Rev Neurosci 30:425-450.

Miura E, Iijima T, Yuzaki M, Watanabe M (2006) Distinct expression of Cbln family mRNAs in developing and adult mouse brains. Eur J Neurosci 24:750-760.

Mizuno Y, Takahashi K, Totsune K, Ohneda M, Konno H, Murakami O, Satoh F, Sone M, Takase S, Itoyama Y, Mouri T (1995) Decrease in cerebellin and corticotropin-releasing hormone in the cerebellum of olivopontocerebellar atrophy and Shy-Drager syndrome. Brain Res 686:115-118.
Morando L, Cesa R, Harvey RJ, Strata P (2005) Spontaneous electrical activity and structural plasticity in the mature cerebellar cortex. Ann NY Acad Sci 1048:131-140.

O’Brien RJ, Xu D, Petralia RS, Steward O, Huganir RL, Worley P (1999) Synaptic clustering of AMPA receptors by the extracellular immediateearly gene product Narp. Neuron 23:309-323.

Okabe S, Miwa A, Okado H (2001) Spine formation and correlated assembly of presynaptic and postsynaptic molecules. J Neurosci 21:6105-6114.

Pajvani UB, Du X, Combs TP, Berg AH, Rajala MW, Schulthess T, Engel J, Brownlee M, Scherer PE (2003) Structure-function studies of the adipocyte-secreted hormone Acrp30/adiponectin. Implications fpr metabolic regulation and bioactivity. J Biol Chem 278:9073-9085.

Pang Z, Zuo J, Morgan JI (2000) Cbln3, a novel member of the precerebellin family that binds specifically to Cbln1. J Neurosci 20:6333-6339.

Rhyu IJ, Abbott LC, Walker DB, Sotelo C (1999) An ultrastructural study of granule cell/Purkinje cell synapses in tottering $(\mathrm{tg} / \mathrm{tg})$, leaner $(\operatorname{tg}(\mathrm{la}) /$ $\operatorname{tg}(\mathrm{la}))$ and compound heterozygous tottering/leaner $(\operatorname{tg} / \operatorname{tg}(\mathrm{la}))$ mice. Neuroscience 90:717-728.

Sdrulla AD, Linden DJ (2007) Double dissociation between long-term depression and dendritic spine morphology in cerebellar Purkinje cells. Nat Neurosci 10:546-548.

Sotelo C (1975) Anatomical, physiological and biochemical studies of the cerebellum from mutant mice. II. Morphological study of cerebellar cortical neurons and circuits in the weaver mouse. Brain Res 94:19-44.

Stevens B, Allen NJ, Vazquez LE, Howell GR, Christopherson KS, Nouri N, Micheva KD, Mehalow AK, Huberman AD, Stafford B, Sher A, Litke AM, Lambris JD, Smith SJ, John SW, Barres BA (2007) The classical complement cascade mediates CNS synapse elimination. Cell 131:1164-1178.

Tada T, Sheng M (2006) Molecular mechanisms of dendritic spine morphogenesis. Curr Opin Neurobiol 16:95-101.

Takeuchi T, Miyazaki T, Watanabe M, Mori H, Sakimura K, Mishina M (2005) Control of synaptic connection by glutamate receptor $\delta 2$ in the adult cerebellum. J Neurosci 25:2146-2156.

Trachtenberg JT, Chen BE, Knott GW, Feng G, Sanes JR, Welker E, Svoboda $\mathrm{K}$ (2002) Long-term in vivo imaging of experience-dependent synaptic plasticity in adult cortex. Nature 420:788-794.

Tsao TS, Tomas E, Murrey HE, Hug C, Lee DH, Ruderman NB, Heuser JE, Lodish HF (2003) Role of disulfide bonds in Acrp30/adiponectin structure and signaling specificity. Different oligomers activate different signal transduction pathways. J Biol Chem 278:50810-50817.

Umemori H, Linhoff MW, Ornitz DM, Sanes JR (2004) FGF22 and its close relatives are presynaptic organizing molecules in the mammalian brain. Cell 118:257-270.

Wada C, Ohtani H (1991) Molecular cloning of rat cerebellin-like protein cDNA which encodes a novel membrane-associated glycoprotein. Brain Res Mol Brain Res 9:71-77.

Xu D, Hopf C, Reddy R, Cho RW, Guo L, Lanahan A, Petralia RS, Wenthold RJ, O'Brien RJ, Worley P (2003) Narp and NP1 form heterocomplexes that function in developmental and activity-dependent synaptic plasticity. Neuron 39:513-528.

Yuzaki M (2008) Cbln and C1q family proteins-new transneuronal cytokines. Cell Mol Life Sci, in press. 